\title{
Spatio-temporal calibration of Hargreaves-Samani model in the Northern Region of Nigeria
}

\author{
Akinwale Temitope Ogunrinde ${ }^{1,2,3}$ (D) Israel Emmanuel ${ }^{4} \cdot$ Mike A. Enaboifo $^{3} \cdot$ Taiwo Adedayo Ajayi $^{1}$. \\ Quoc Bao Pham ${ }^{5}$ (D)
}

Received: 2 September 2021 / Accepted: 11 December 2021 / Published online: 28 December 2021

(c) The Author(s) 2021

\begin{abstract}
One of the significant components of the hydrological cycle is evapotranspiration. Monthly meteorological parameters of 35 years from 19 meteorological stations across the Northern Region of Nigeria (NRN) were obtained and utilized for the calibration of Hargreaves-Samani (HS) model by comparing between potential evapotranspiration (ET ${ }_{\mathrm{o}}$ ) values estimated from the original HS and the Penman-Monteith (FAO-56 PM) models. The calibrated HS equation was assessed using trend patterns and some statistical indices. The average value of root mean square error (RMSE) and the mean absolute error (MAE) decreased by 37.1 and $40 \%$, respectively, after the calibration of the model. Also, the correlation coefficients $(R)$ of stations that had values $>0.8$ increased from 6 to 11 and the minimum $R$ value increased by $12 \%$ above that of the original HS equation. The trend and spatial map of the statistical tests conducted also indicate better performance in most climatic regions after calibration. The precision of the HS equation improved significantly after calibration for semi-arid, humid, and sub-humid regions. However, few stations in the semi-arid, humid, and sub-humid regions did not show drastic improvement due to the peculiarity of the location and high variations in the wind speed and relative humidity parameters.
\end{abstract}

\section{Introduction}

The necessity to efficiently manage the water resources and the agricultural sectors in a developing country where subsistence farming is the most available job is very important and must be given priority in order to avert serious economic and environmental challenges. It is even more pertinent if the area under consideration is classified under arid or semi-arid regions (Jerin et al. 2021; Salam and Islam 2020).

Quoc Bao Pham

quoc_bao.pham@us.edu.pl

1 Department of Agricultural and Environmental Engineering, Federal University of Technology, P.M.B. 704, AkureAkure, Nigeria

2 Department of Agricultural and Bioenvironmental Engineering, Federal College of Agriculture, Ishiagu, Nigeria

3 Department of Agricultural Engineering, Faculty of Engineering, University of Benin, Benin City, Nigeria

4 Department of Physics, Federal University of Technology, Akure, Nigeria

5 Faculty of Natural Sciences, Institute of Earth Sciences, University of Silesia in Katowice, Będzińska street 60, 41-200, Sosnowiec, Poland
The issue of climate change which has led to more drought occurrences in many parts of the earth, most significantly in the Sahel region of West Africa, in recent decades calls for efficient management of available water resources (Ibebuchi 2021; Dong and Sutton 2015; Lele and Lamb 2010; Dai et al. 2004; Sultan and Janicot 2000). Evapotranspiration (ET) is very essential to quantify the amount of water that will be needed to sustain a crop especially when rainfall is not sufficient. The accurate measurement of changes in ET is very important for modeling ecological and hydrological changes and natural plant habitat (Heydari and Heydari 2014).

ET is a significant parameter in calculating the energy and water balances on the surface of the earth. Understanding this parameter on a spatiotemporal scale will provide answer to some pertinent questions in climatology, hydrology, agronomy, and ecology (Animashaun et al. 2020; Rivas and Caselles 2004). In addition, the knowledge of ET is key for strategizing a viable economic use of the available water resources (Tellen 2007). Efficient irrigation water requirement is usually estimated using potential evapotranspiration $\left(\mathrm{ET}_{\mathrm{o}}\right)$. Therefore, many irrigation experts make use of $\mathrm{ET}_{\mathrm{o}}$ and crop coefficients $(\mathrm{Kc})$ to compute the irrigation water required for different crops (Tellen 2007). Despite the fact 
that there are many model equations for calculating $\mathrm{ET}_{\mathrm{o}}$ from meteorological data, there happened to be no rigid agreement on the acceptability of any particular model for a climatic region, but Penman-Monteith (FAO-56 PM) model is referred to as standard because of its good accuracy and consistency when compared with other models (Allen et al. 1998). The main benefit of the FAO-56 PM model is that it has taken into consideration the principles of aerodynamics and thermodynamic components of the climate system. The FAO-56 PM model has been adopted and used for many climatic regions (e.g., Mohammadi and Mehdizadeh 2020; Ogunrinde et al. 2020a; Li et al. 2018; Tellen 2007; Heydari and Heydari 2014; Ventura et al. 1999). Although the FAO56 PM model has a general acceptability for many climates, the need for many weather parameters that are usually not available at many meteorological stations, especially in the developing countries, have limited its usage (Pereira and Pruitt 2004).

It has been observed that the Hargreaves-Samani (HS) model of 1985, which uses only temperature data, has the tendency to provide acceptable $\mathrm{ET}_{\mathrm{o}}$ similar to that of FAO$56 \mathrm{PM}$ model for arid region. However, there is a need for the local calibration of this model in humid, sub-humid, and semi-arid climatic regions (Zhu et al. 2019; Gavilan et al. 2006). It has also been established that HS model usually overestimate $\mathrm{ET}_{\mathrm{o}}$ in humid climate area and underestimate in arid regions, thereby making it not too effective in managing water resources without calibration (Trajkovic 2005).

Several studies have showed the efficiency of the HS model in relation to FAO-56 PM model for estimating $\mathrm{ET}_{\mathrm{o}}$. Hargreaves (1994) compared the $\mathrm{ET}_{\mathrm{o}}$ data collected from well-established lysimeters across many climatological regions using Hargreaves equation with PM equation on weekly, monthly, and yearly basis. He discovered that the Hargreaves equation indicated a very similar $\mathrm{ET}_{\mathrm{o}}$ result to that of the PM equation. In addition, Droogers and Allen (2002) showed a significant correlation between the monthly estimates of $\mathrm{ET}_{\mathrm{o}}$ using HS and PM equations. However, an insignificant correlation was noted between HS and PM methods when estimated on daily and weekly basis for five different climatic regions except at semi-arid area (Stockle et al. 2004). A more extensive comparative study between Hargreaves and the PM method in Spain that covered 86 synoptic stations, most of which is under the semi-arid regions, concluded that there is a need for regional calibration of the Hargreaves method using temperature and wind data (Gavilan et al. 2006). In another similar study carried out in Iran by Fooladmand and Sepaskhah (2005), a calibration of the Hargreaves equation was done for estimating the monthly $\mathrm{ET}_{\mathrm{o}}$ in Bajgah area in Fars province, which is a semi-arid region in Iran based on the PM equation. Also, a study by Heydari and Heydari (2014) in arid and semi-arid areas of Iran showed that the original coefficient value $(0.0023)$ of the Hargreaves equation ranged between 0.0013 and 0.0043 . Although some $\mathrm{ET}_{\mathrm{o}}$ models have been calibrated for many countries in the world, for example, in Iran (e.g., Valipour 2015; Heydari and Heydari 2014), China (e.g., Zhu et al. 2019; Gao et al. 2015), Poland (e.g., Bogawski and Bednorz 2014), USA (e.g. Thepadia and Martinez 2012), and Southeast Australia (Azhar and Perera 2011), paucity of data and lack of sufficient information in terms of suitable $\mathrm{ET}_{\mathrm{o}}$ model to be applied for the Northern Region of Nigeria (NRN) are posing a serious challenge to the limited water resources.

The NRN is located between latitude 6 and $14^{\circ} \mathrm{N}$ of the West Africa coast covering some part of Sahel, Sudan, and Guinea savannahs. The Sahelian region cuts across several countries in western and central Africa. For example, in the Senegal River Valley (SRV), the major produced crop is rice and the water resources that can be applied for irrigation is becoming very scarce and expensive (Djaman et al. 2015). Like in the NRN, SRV, and many other Sahelian regions, efficient management of water has not been considered as very important; therefore, irrigation schemes are poorly developed (Djaman et al. 2015). In SRV, it is noted that irrigation requirement is the main factor to be considered for the cost of rice production. This is due to the fact that the cost of pumping irrigation water is very expensive, thereby making $30 \%$ of the total cost of operation (Comas et al. 2012). In order to limit cost or efficiently manage water resources, there is a need for accuracy in the determination of irrigation water requirement in the SRV, NRN, and other Sahelian regions.

Some notable studies carried out in Nigeria as regards the estimation of $\mathrm{ET}_{\mathrm{o}}$ include, e.g., Akpootu and Iliyasu (2017), Ejieji (2011), and Adeboye et al. (2009). All these studies succeeded in comparing many $\mathrm{ET}_{\mathrm{o}}$ models with the FAOPM 56 without actually calibrating or developing a localized $\mathrm{ET}_{\mathrm{o}}$ for any region in Nigeria. To compensate for this and other identified gaps, the aims of this study are (1) to evaluate the performance of the original Hargreaves-Samani model against FAO-56 PM, (2) to calibrate the Hargreaves-Samani equation for Northern Region of Nigeria (NRN) based on FAO-56 PM model for estimating $\mathrm{ET}_{\mathrm{o}}$, and (3) to assess the efficiency of $\mathrm{ET}_{\mathrm{o}}$ estimated by the calibrated HS equation during the testing phase.

\section{Description of the study area and data collection}

The NRN covers about $75 \%$ of the total land mass of Nigeria $\left(925,796 \mathrm{~km}^{2}\right)$. This region has two seasons: the dry and the wet seasons. The dry season ranges from 4 to 7 months depending on the climatic zone. Rainfall distribution within the NRN ranges from about 400 to $1500 \mathrm{~mm}$ depending on the latitude of the location under consideration (Oguntunde 
et al. 2011). The monthly climatic variables of 19 stations which include relative humidity, minimum and maximum temperatures, wind speed, and sunshine hours utilized for this study spanned through January 1981 to December 2015. The relative humidity and minimum and maximum temperature parameters were obtained from Nigeria Meteorological Agency (NIMET) headquarters, Abuja, Nigeria. However, since wind speed and sunshine duration datasets were not readily available in most of the stations during the study period, bias-corrected datasets were downscaled from ERA-interim reanalyzed data (Berrisford et al. 2011). For the present study, the reanalyzed sets were used because they had strong correlation coefficient $(>0.8)$ with observed data as indicated by Oluleye and Adeyewa (2016) using some meteorological station datasets in Nigeria.

The wind speed data utilized for this study consist of monthly $\mathrm{u}$ wind and $\mathrm{v}$ wind components. Therefore, wind speed magnitude at $2 \mathrm{~m}$ height $\left(\mathrm{U}_{2}\right)$ was calculated using Eq. (1):

$U=\sqrt{u^{2}+v^{2}}$

The quality of wind speed, relative humidity, sunshine hours, and solar radiation was verified using the methodology suggested by Allen et al. (1998). The solar radiation $\left(R_{s}, \mathrm{MJ} \mathrm{m}^{-2} \mathrm{day}^{-1}\right)$ was computed using Angstrom equation, which links extraterrestrial radiation and sunshine hours to solar radiation:

$R_{s}=\left(a_{s}+b_{s} \frac{n}{N}\right) R_{a}$

where

$a_{s}$ and $b_{s}$ are regression constants, which indicate the fraction of extraterrestrial radiation reaching the earth on clear days. The values adopted for $a_{s}$ and $b_{s}$ are 0.25 and 0.50 , respectively.

$n$ is the actual duration of sunshine hours.

$N$ is the maximum possible of sunshine or daylight hours.

$R_{a}$ is the extraterrestrial radiation $\left(\mathrm{MJ} \mathrm{m}^{-2}\right.$ day $\left.^{-1}\right)$.

The $N$ and $R_{a}$ were determined using the following equations:

$N=\frac{24}{\pi} \omega_{s}$

$R_{a}=\frac{24(60)}{\pi} G_{s c} d_{r}\left[\omega_{s} \sin (\varphi) \sin (\delta)+\cos (\varphi) \sin \left(\omega_{s}\right)\right]$

where.

$G_{s c} 0.0820 \mathrm{MJ} \mathrm{m}^{-2} \mathrm{~min}^{-1}$.

$d_{r}$ is the inverse relative distance of earth-sun.

$\varphi$ is latitude (rad).

$\delta$ is solar declination.

$\omega_{s}$ is the sunset hour angle (rad). $d_{r}=1+0.033 \cos \left(\frac{2 \pi}{365} J\right)$

$\delta=0.409 \sin \left(\frac{2 \pi}{365} J-1.39\right)$

$\omega_{s}=\arccos [-\tan (\varphi) \tan (\delta)]$

where $J$ is the number of days in the year between 1 January and 31 December. Corresponding $J$ values for all the days of the year can be estimated using an algorithm in Table 2.5 Annex 2, FAO 56 paper (Allen et al. 1998).

To ascertain the quality of relative humidity data, actual vapor pressure $e_{a}$ was computed based on the assumption that the dew-point temperature is similar to the minimum temperature $\left(T_{\min }\right)$ values, there using the following equation (Allen et al. 1998):

$e_{a}=e^{o}\left(T_{\min }\right)=0.611 \exp \left[\frac{17.27 T_{\min }}{T_{\min }+237.3}\right]$

The summarized detail of these variables and other station parameters are contained in Table 1, while Fig. 1 shows the location of each station in the study area (NRN) and Fig. 2a-c shows the long-term monthly variation temperature, wind speed, and sunshine hour datasets.

\section{Methodology}

The two models used in estimating $\mathrm{ET}_{\mathrm{o}}$ for all the 19 stations of the study area are FAO-56 PM and HS (1985) equations.

\subsection{PM model}

In the present study, FAO-56 PM model which has been generally referred and accepted as a standard model for estimating $\mathrm{ET}_{\mathrm{o}}$ was adopted for calibrating $\mathrm{HS} \mathrm{ET}_{\mathrm{o}}$ model. This equation has been used to estimate $\mathrm{ET}_{\mathrm{o}}$ for so many regions and climate because of its versatility (e.g., Jerin et al. 2021; Ogunrinde et al. 2020b; Heydari and Heydari 2014; Ghamarnia et al. 2012). The FAO-56 PM general model for estimating $\mathrm{ET}_{\mathrm{o}}$ on a daily basis is given in Eq. (9) (Allen et al. 1998):

$E T_{O}=\frac{0.408 \Delta\left(R_{n}-G\right)+\gamma\left[\frac{900}{T+273}\right] U_{2}\left(e_{s}-e_{a}\right)}{\Delta+\gamma\left(1.0+0.34 U_{2}\right)}$

where $\mathrm{ET}_{\mathrm{o}}\left(\mathrm{mm} \mathrm{day}^{-1}\right)$ stands for reference crop evapotranspiration; $\Delta\left(\mathrm{kPa}^{\circ} \mathrm{C}^{-1}\right)$ represents the slope of the saturation vapor pressure; $R_{n}\left(\mathrm{MJ} \mathrm{m}^{-2}\right.$ day $\left.^{-1}\right)$ stands for net radiation term; $G\left(\mathrm{MJ} \mathrm{m}^{-2} \mathrm{day}^{-1}\right)$ is the soil heat flux term; $T\left({ }^{\circ} \mathrm{C}\right)$ stands for average air temperature; $U_{2}\left(\mathrm{~m} \mathrm{~s}^{-1}\right)$ 
Table 1 Summarized meteorological parameters for the study locations

\begin{tabular}{|c|c|c|c|c|c|c|c|c|c|c|}
\hline $\mathrm{S} / \mathrm{N}$ & Stations & $\begin{array}{l}\text { Latitude } \\
\text { (dec. deg) }\end{array}$ & $\begin{array}{l}\text { Longitude } \\
\text { (dec. deg) }\end{array}$ & Elevation $(\mathrm{m})$ & Period (years) & $T_{\max }\left({ }^{\circ} \mathrm{C}\right)$ & $T_{\min }\left({ }^{\circ} \mathrm{C}\right)$ & $\begin{array}{l}\text { Precipitation } \\
\left(\mathrm{mm} \text { year }^{-1}\right)\end{array}$ & $\mathrm{U}_{2}\left(\mathrm{~m} \mathrm{~s}^{-1}\right)$ & $\begin{array}{l}\text { Sunshine dura- } \\
\text { tion }\left(\text { h day }^{-1}\right)\end{array}$ \\
\hline 1 & Sokoto & 13.02 & 5.25 & 350.80 & 1981-2015 & 35.47 & 23.16 & 657.29 & 2.53 & 10.62 \\
\hline 2 & Katsina & 13.02 & 7.68 & 517.60 & 1981-2015 & 33.77 & 19.98 & 562.47 & 2.47 & 10.67 \\
\hline 3 & Nguru & 12.88 & 10.47 & 343.10 & 1981-2015 & 35.33 & 20.69 & 417.11 & 2.73 & 10.78 \\
\hline 4 & Gusau & 12.17 & 6.70 & 463.90 & 1981-2015 & 33.71 & 20.13 & 908.67 & 1.80 & 10.46 \\
\hline 5 & Kano & 12.05 & 8.20 & 472.50 & 1981-2015 & 33.60 & 20.95 & 1051.22 & 2.29 & 10.56 \\
\hline 6 & Potiskum & 11.70 & 11.08 & 414.80 & 1981-2015 & 34.84 & 21.12 & 668.84 & 2.30 & 10.67 \\
\hline 7 & Zaria & 11.10 & 7.68 & 110.90 & 1981-2015 & 32.16 & 19.36 & 966.00 & 2.43 & 10.27 \\
\hline 8 & Yelwa & 10.88 & 4.75 & 244.00 & 1981-2015 & 34.57 & 22.53 & 999.84 & 2.15 & 10.22 \\
\hline 9 & Kaduna & 10.60 & 7.45 & 645.40 & 1981-2015 & 31.91 & 19.45 & 1208.04 & 2.17 & 10.06 \\
\hline 10 & Bauchi & 10.28 & 9.82 & 609.70 & 1981-2015 & 32.00 & 19.56 & 1122.20 & 1.88 & 10.44 \\
\hline 11 & Jos & 9.87 & 8.75 & 1217.00 & 1981-2015 & 27.83 & 15.50 & 1231.09 & 1.64 & 10.20 \\
\hline 12 & Minna & 9.62 & 6.53 & 256.40 & 1981-2015 & 33.49 & 22.75 & 1183.67 & 1.46 & 9.73 \\
\hline 13 & Abuja & 9.25 & 7.00 & 343.10 & 1981-2015 & 33.22 & 22.13 & 1163.98 & 1.38 & 9.65 \\
\hline 14 & Yola & 9.23 & 12.47 & 186.10 & 1981-2015 & 34.89 & 22.41 & 669.54 & 1.86 & 10.33 \\
\hline 15 & Bida & 9.10 & 6.02 & 144.30 & 1981-2015 & 33.78 & 22.69 & 1142.68 & 1.29 & 9.66 \\
\hline 16 & Ilorin & 8.48 & 4.58 & 307.40 & 1981-2015 & 32.27 & 21.79 & 1238.47 & 1.33 & 9.48 \\
\hline 17 & Ibi & 8.18 & 9.75 & 110.70 & $1981-2015$ & 33.46 & 22.16 & 1203.95 & 2.29 & 9.75 \\
\hline 18 & Lokoja & 7.78 & 6.73 & 62.50 & 1981-2015 & 33.54 & 23.18 & 1227.15 & 1.65 & 9.37 \\
\hline 19 & Makurdi & 7.73 & 8.53 & 112.90 & $1981-2015$ & 33.39 & 22.37 & 1172.52 & 1.88 & 9.57 \\
\hline
\end{tabular}

Note: $T_{\max }$ and $T_{\min }$ represent maximum and minimum temperature, respectively. $\mathrm{U}_{2}$ represents wind speed at $2 \mathrm{~m}$ height

Fig. 1 Map of the study area

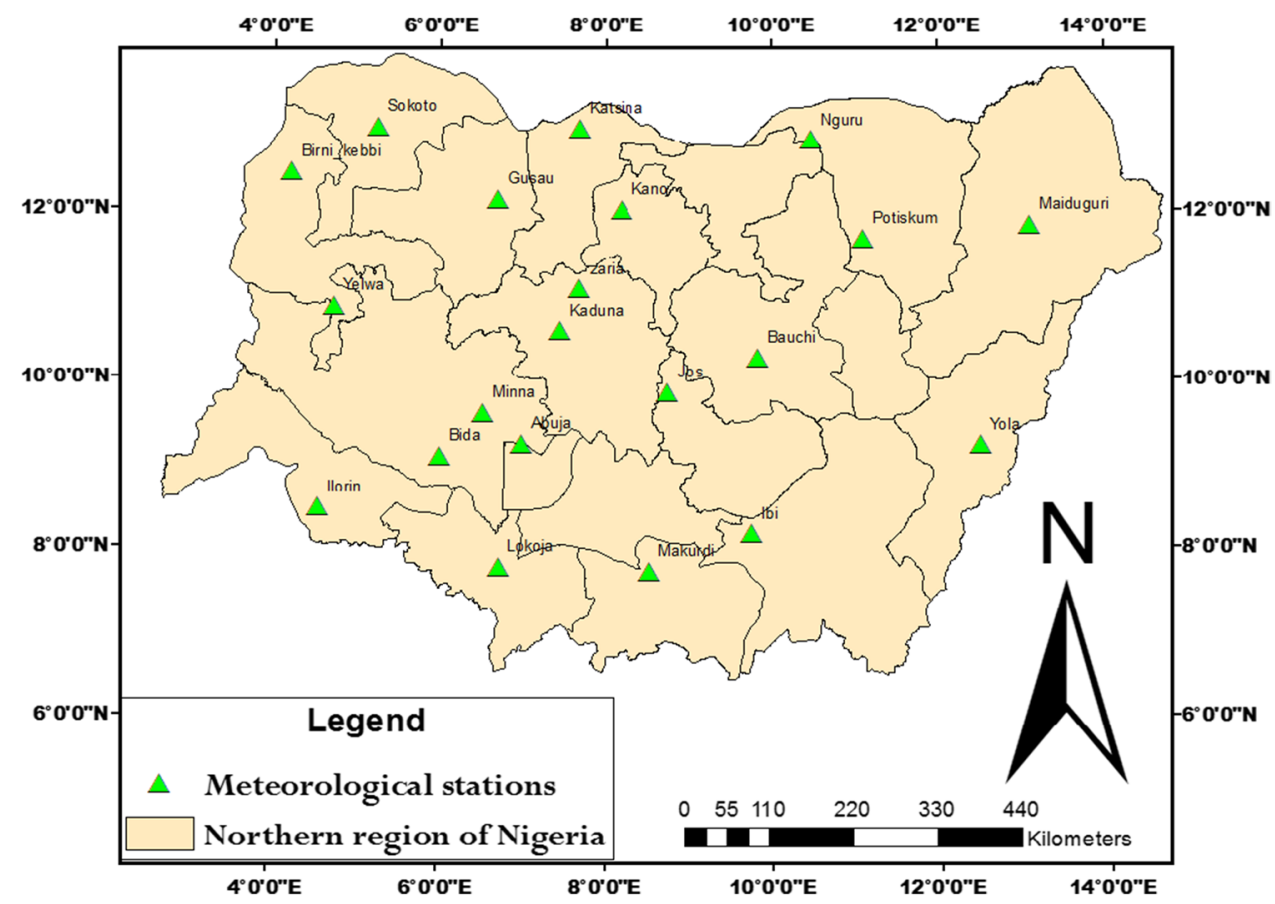

represents wind speed taken at the height of $2 \mathrm{~m} ; e_{s}-e_{a}$ $(\mathrm{kPa})$ represents the vapor pressure deficit in the air; $\gamma(\mathrm{kPa}$ ${ }^{\circ} \mathrm{C}^{-1}$ ) stands for the psychometric constant.

Very few of the synoptic stations were sited at the airport where an automatic weather station has the capacity of recording wind speed, temperature, relative humidity, and radiation datasets on an hourly or daily basis. However, most of the other synoptic stations have facilities such as standard rain gauges, wind anemometer, and air thermometers. The detailed procedure for estimating all the parameters in the 

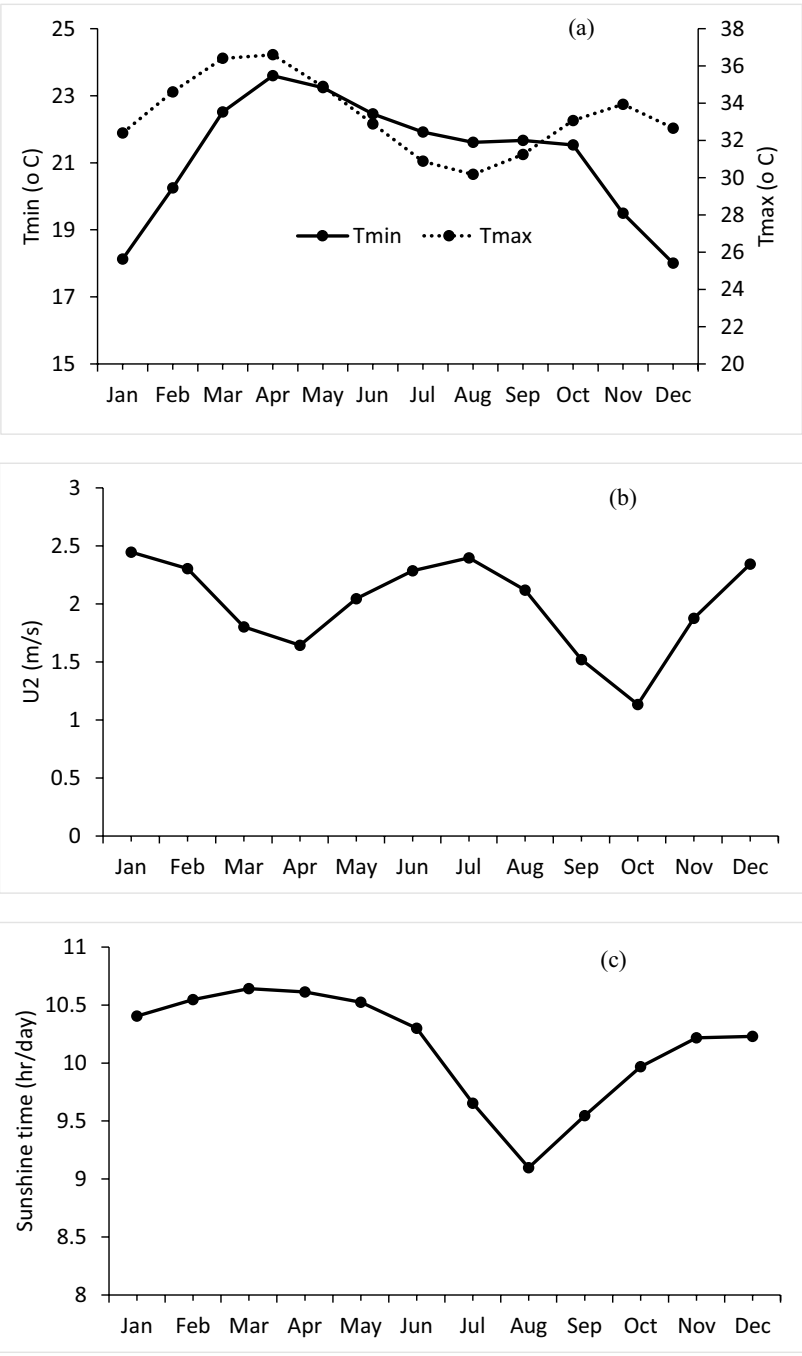

Fig. 2 Long-term historical average monthly distribution of a $T_{\text {min }}$ and $T_{\max }, \mathbf{b}$ sunshine hours, and $\mathbf{c}$ wind speed of the study area

FAO-56 PM model from the relevant weather variables has been established in the FAO-56 paper (Allen et al. 1998).

\subsection{Hargreaves-Samani (HS) model}

HS was developed considering the fact that there are regions or areas where there will not be adequate climatic/weather parameters needed to estimate the original Penman equation or other available $\mathrm{ET}_{\mathrm{o}}$ models (Hargreaves and Samani 1985). The 1985 version of the HS ET is presented in Eq. (10).

$E T_{o}=0.0023 \times R_{a} \times\left(\frac{T_{\max }+T_{\min }}{2}+17.80\right) \times\left(T_{\max }-T_{\min }\right)^{0.5}$

where $\mathrm{ET}_{\mathrm{o}}\left(\mathrm{mm} \mathrm{day}^{-1}\right)$ represents the potential evapotranspiration estimates; $R_{a}\left(\mathrm{~mm} \mathrm{day}^{-1}\right)$ stands for the extraterrestrial radiation which usually requires the day of the year and latitude; $T_{\max }$ and $T_{\min }$ represent the maximum and minimum air temperatures; the default $\mathrm{C}$ and $\mathrm{E}$ values are 0.0023 and 0.5 , respectively, which represent empirical constants for the original HS model mostly conducted in an arid climatic region.

\subsection{Local calibration for Hargreaves-Samani model}

Excel Solver can be used to obtain a prime value for an objective function in a target cell. It is a tool that also depends on a number of cells that are connected to the objective function in the target cell, and it utilizes the values in the changeable cells to adjust the value of the target cell. Zhu et al. (2019) indicate that $\mathrm{C}$ and $\mathrm{E}$ parameters in HS model is a problem that can be fixed using a nonlinear optimization means. For this research, Excel Solver has been identified as a means to optimize these parameters. For the parameterization of HS model, there are two approaches that can be used in Excel software. The approaches are the Generalized Reduced Gradient (GRG) solver (Lasdon and Smith 1992) and the evolutionary solver (Barati 2013). The GRG approach was adopted because of its universality and acceptability in similar studies (Zhu et al. 2019). More detailed explanation on the optimization algorithms of Excel software using solver can be found on Premium Solver Platform (2010).

The monthly $\mathrm{ET}_{\mathrm{o}}$ values computed using HS and FAO-56 PM models were divided into two periods, which covered for calibration and validation distinctly. Twenty-seven and eight years were used for the calibration and validation phases, respectively. During the calibration phase, the FAO-56 PM method was used for calibrating parameters $\mathrm{C}$ and $\mathrm{E}$ of the HS equation using the Solver tool in Microsoft Excel 2016 predicated on the nonlinear least squares technique that is targeted to reduce the residual sum of squares of the estimated $\mathrm{ET}_{\mathrm{o}}$ from the FAO-56 PM and HS equations. After completing the calibration for all the 19 meteorological stations considered in the present study, the calibrated parameters $(\mathrm{C}$ and $\mathrm{E})$ were used to replace the original $\mathrm{C}$ and $\mathrm{E}$ values in the original HS equations in the next 8 years of the meteorological data in order to substantiate the calibrated HS equation. The statistical assessment carried out on the HS equation was predicated on the results obtained from the validation period.

\subsection{Aridity index}

Aridity or climate index can be defined as a pointer for the intensity of dryness of the climate of a region/area (Gocic and Trajkovic 2013). For this work, the UNEP index (UNEP 1992) was adopted to serve as an indicator for the climate classification of all the 19 meteorological stations. The classification was based on the ratio of rainfall $(\mathrm{R})$ to reference 
evapotranspiration $\left(\mathrm{ET}_{\mathrm{o}}\right)$. The $\mathrm{ET}_{\mathrm{o}}$ was estimated using FAO-56 Penman-Monteith (FAO-56 PM) equation.

\subsection{Spatial analysis}

To show the geographical spread of the calibrated C and $\mathrm{E}$ parameters, the root mean square error (RMSE), mean absolute error (MAE), and correlation coefficient $(R)$ within the study area, ArcGIS 10.4 software desktop edition was used. To illustrate the spatial maps, the inverse distance weighting (IDW) interpolation technique was utilized to convert points to spatial datasets. The IDW presumes the unmeasured points by estimating it from the surrounding nearest measured points. The equation for estimating the unmeasured points is as follows (Zinat et al. 2020):

$\widehat{Z}\left(x_{o}\right)=\frac{\sum_{i=1}^{n} Z\left(x_{i}\right) d_{i j}^{-r}}{\sum_{i=1}^{n} d_{i j}^{-r}}$

where $x_{o}$ is the inference point and the $x_{i}$ are the sampled points within a study area. The weight parameter $(r)$ is linked to distance by $d_{i j}$, which is the distance between the inference point and sampled points.

The rationalization behind using the IDW is its wide usage in comparison with other interpolation models like natural neighbors, spline, and kriging (Zinat et al. 2020).

\subsection{Statistical assessment}

In order to evaluate the error margins between original $\mathrm{HS}$ and FAO-56 PM, and calibrated HS and FAO-56 PM, some statistical tests carried out include root mean square error (RMSE), mean absolute error (MAE), and coefficient of correlation $(R)$. All these tests were done for all the stations using Eqs. (11) to (13).

$$
\begin{aligned}
& M A E=\frac{1}{n} \sum_{i=1}^{n}\left|\left(H_{i}-P_{i}\right)_{t}\right| \\
& R M S E=\sqrt{\frac{\sum_{i=1}^{n}\left(H_{i}-P_{i}\right)^{2}}{n}} \\
& R=\frac{\sum\left(H_{i}-\bar{H}\right)\left(P_{i}-\bar{P}\right)}{\sqrt{\sum\left(H_{i}-\bar{H}\right)^{2} \sum\left(P_{i}-\bar{P}\right)^{2}}}
\end{aligned}
$$

where $n$ stands for the number of data in months; $H_{i}$ represents the original or calibrated $\mathrm{HS} \mathrm{ET}_{\mathrm{o}}$ models; $P_{i}$ represents the $\mathrm{ET}_{\mathrm{o}}$ estimated from FAO-56 PM.

\section{Results and discussion}

\subsection{Assessment of the original HS model}

Figure $3 \mathrm{a}-\mathrm{c}$ shows the spatial representations of the three statistical parameters calculated from the FAO-56 PM and the original HS equations. As indicated, the precision of the $\mathrm{ET}_{\mathrm{o}}$ values from the original HS equation varied significantly among the four climatic regions identified from the study area (Table 2). For all the 19 meteorological stations, the MAE ranged from 0.41 to $0.87 \mathrm{~mm} \mathrm{day}^{-1}$ with an average value of $0.58 \mathrm{~mm} \mathrm{day}^{-1}$. Most of the meteorological stations in the humid climate region recorded the lower MAE values in comparison with the values in other climatic regions. The highest MAE value $\left(0.87 \mathrm{~mm} \mathrm{day}^{-1}\right)$ was noted in an arid zone. The RMSE values within the study area were between 0.48 and $1.00 \mathrm{~mm} \mathrm{day}^{-1}$, with a mean value of $0.67 \mathrm{~mm}$ day $^{-1}$. The distribution pattern of MAE is very similar to that of RMSE (Fig. 3a, b). The correlation coefficient $(R)$ values within all the four climatic regions indicated from the study area ranged between 0.56 and 0.87 , with an average value of 0.73 . The arid region recorded the highest $(0.87)$ while the least is noted at the sub-humid region (0.56). The reduction in the correlation coefficients from the arid to the sub-humid region may be due to the role of relative humidity. This is in line with the observation of Zhu et al. (2019).

Judging by the correlation coefficient, the precision of the $\mathrm{ET}_{\mathrm{o}}$ computed from the original HS equation in the arid climatic region is relatively higher than other climatic regions. In line with the findings of some researchers (Zhu et al. 2019; Almorox and Grieser 2016), the windy climate as a result of the closeness of Sokoto meteorological station (arid region) to the Sahara Desert may be the influence responsible for the considerably higher $R$ between the original HS model and FAO-PM model than other climatic regions (i.e., semi-arid, sub-humid, and humid). However, the original HS model with the recommended parameters (C and $\mathrm{E}$ ) was not consistently able to give reliable results in most parts of the NRN. Therefore, the local calibration of these two parameters under different climate regions is essential to derive better precision for $\mathrm{HS} \mathrm{ET}_{\mathrm{o}}$ model.

\subsection{The estimation of $C$ and $E$ parameters of the HS equation}

The spatial distribution pattern for both $\mathrm{C}$ and $\mathrm{E}$ parameters in the HS equation for the NRN are presented in Fig. $4 \mathrm{a}$ and $\mathrm{b}$. The parameter $\mathrm{C}$ ranges between 0.0031 and 0.0096 with an average value of 0.0047 . Although there is no observed significant trend within the four climatic 
Fig. 3 Maps showing variation in the statistical parameters calculated using the original HS and FAO-56 PM models over the NRN: a MAE, b RMSE, and $\mathbf{c} R$
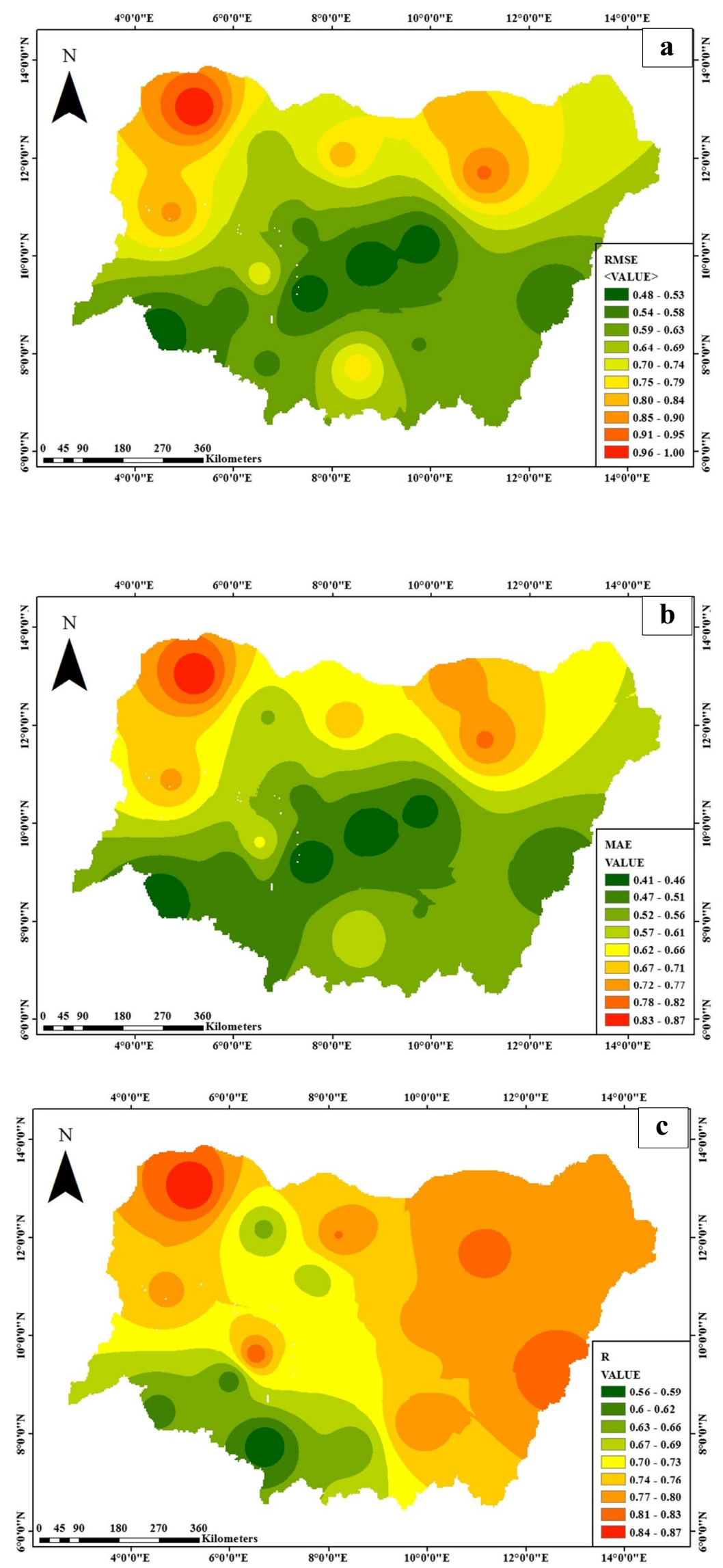
Table 2 Average of annual rainfall, reference evapotranspiration, and aridity index for 19 meteorological stations in the NRN

\begin{tabular}{llclll}
\hline S/N & Station & $\begin{array}{l}\text { Rainfall } \\
(\mathrm{mm} \\
\left.\text { year }^{-1}\right)\end{array}$ & $\begin{array}{l}\mathrm{ET}_{\mathrm{o}}(\mathrm{mm} \\
\left.\mathrm{year}^{-1}\right)\end{array}$ & $\begin{array}{l}\text { Aridity } \\
\text { index }\end{array}$ & Climate \\
\hline 1 & Nguru & 417.11 & 2288.66 & 0.18 & Arid \\
2 & Sokoto & 657.29 & 2186.21 & 0.30 & Semi-arid \\
3 & Katsina & 562.47 & 2146.98 & 0.26 & Semi-arid \\
4 & Gusau & 908.67 & 1972.94 & 0.46 & Semi-arid \\
5 & Potiskum & 668.84 & 2135.25 & 0.31 & Semi-arid \\
6 & Zaria & 966.00 & 2012.82 & 0.50 & Semi-arid \\
7 & Yelwa & 999.84 & 2067.43 & 0.48 & Semi-arid \\
8 & Yola & 669.54 & 2075.32 & 0.32 & Semi-arid \\
9 & Kano & 1051.22 & 2080.72 & 0.51 & Sub-humid \\
10 & Ibi & 1203.95 & 1980.48 & 0.61 & Sub-humid \\
11 & Makurdi & 1172.52 & 1902.28 & 0.62 & Sub-humid \\
12 & Kaduna & 1208.04 & 1961.18 & 0.62 & Sub-humid \\
13 & Bauchi & 1122.20 & 1962.31 & 0.57 & Sub-humid \\
14 & Minna & 1183.67 & 1877.64 & 0.63 & Sub-humid \\
15 & Abuja & 1163.98 & 1839.87 & 0.63 & Sub-humid \\
16 & Bida & 1142.68 & 1839.09 & 0.62 & Sub-humid \\
17 & Jos & 1231.09 & 1735.22 & 0.71 & Humid \\
18 & Ilorin & 1238.47 & 1769.05 & 0.70 & Humid \\
19 & Lokoja & 1227.15 & 1844.18 & 0.67 & Humid \\
\hline
\end{tabular}

regions, all the stations within the arid and semi-arid regions indicated a $\mathrm{C}$ value greater than the average value except for Bauchi meteorological station (0.0035). The average calibrated values for parameter $\mathrm{C}$ in arid, semiarid, sub-humid, and humid climate regions are 0.0055 , $0.0050,0.0046$, and 0.0040 , respectively. These observations indicate that the parameter will change under different climate regions. This is similar to some earlier studies (Zhu et al. 2019; Pandey et al. 2014). The C parameter was clearly more than the recommended value $(0.0023)$ in all the climate regions. This shows the weakness of this parameter in the estimation of an accurate HS model. The high spatial distribution pattern illustrated by Fig. $4 \mathrm{a}$ shows that the correction of parameter $\mathrm{C}$ is essential for the optimum estimation of $\mathrm{ET}_{\mathrm{o}}$ within the study area. In support, some earlier studies indicated that there is always a large variation in this parameter in different areas, even within a climatic region (Zhu et al. 2019; Xu et al. 2013).

Figure $4 \mathrm{~b}$ reveals the spatial distribution pattern of parameter E within the NRN. The figure shows that the values of the corrected parameter $\mathrm{E}$ do not have a specified trend or pattern within the study area. However, the highest parameter E value is noted at Zaria (0.41) and the lowest at Gusau (0.04), both located in the sub-humid climatic region. Observations from Fig. $4 \mathrm{a}$ and $\mathrm{b}$ are similar to $\mathrm{Zhu}$ et al. (2019) in some provinces in China. The outline/curve line of parameter $\mathrm{E}$ close to 0.5 was indicated mostly in the central and southeastern regions of the NRN, which are mostly located in the humid/sub-humid regions. Regions within the arid and semi-arid climatic zones show values far from the recommended value. Although there are some agreements among most studies carried out on the calibration of HS model, there is still an indication that the original parameters $\mathrm{C}$ and $\mathrm{E}$ should not be fixed for any climatic region. Some of this disparity might have been caused by the method used in the calibration process. Therefore, there is a need to synergize the whole calibration process for a more robust application of the HS equation.

\subsection{Comparison between the calibrated HS and PM models}

The comparisons between the calibrated HS and FAO-56 PM models using MAE, RMSE, and $R$ are illustrated in Fig. 5a-c. The error values indicated by MAE and RMSE in Fig. 5a and b were smaller than that of Fig. $4 a$ and $b$. Table 3 shows the summary of the statistical parameters of $\mathrm{ET}_{\mathrm{o}}$ values from the original and the calibrated HS equation. Clearly, the maximum, minimum, and average values of MAE and RMSE reduced by 46 and $42.1 \%, 46.2$ and $40 \%$, and 43 and $37.1 \%$, respectively. Considering $R$, the maximum, minimum, and average values increased by 2,12 , and $7 \%$, respectively. These results show that the $\mathrm{ET}_{\mathrm{o}}$ values estimated by the calibrated parameters $\mathrm{C}$ and $\mathrm{E}$ were more precise and indicate that the calibrated HS equation can be used to compute $\mathrm{ET}_{\mathrm{o}}$ in most parts of the NRN and other similar climatic regions.

The precision of estimated $\mathrm{ET}_{\mathrm{o}}$ values in all the four climatic regions in the study area reacted differently to the calibrated HS model. The MAE and RMSE ranged from 0.22 to 0.46 and $0.28-0.57$, respectively. These values show a clear distinction from the original HS model. The smallest MAE and RMSE value occurred at Ilorin station, located in the sub-humid climatic region. The $R$ value increased from the southern part of the study area upward north. After calibration, there is an increase in the $R$ values recorded in the NRN at almost all the 19 stations. The sub-humid climatic region experienced the highest improvement in the $R$ value when compared with other climatic regions. Therefore, the outcome from the statistical parameters among the climatic regions show that the precision of the calibrated HS performed better at the sub-humid region than other regions. In general, the calibrated HS model did satisfactorily in the NRN, except in the humid climatic region where there was a slight reduction in the $R$ value (i.e., Jos). This observation is similar to the findings of Zhu et al. (2019) and Pandey et al. (2014). 
Fig. 4 The spatial representation of the modified parameters over NRN: a C parameter, b E parameter
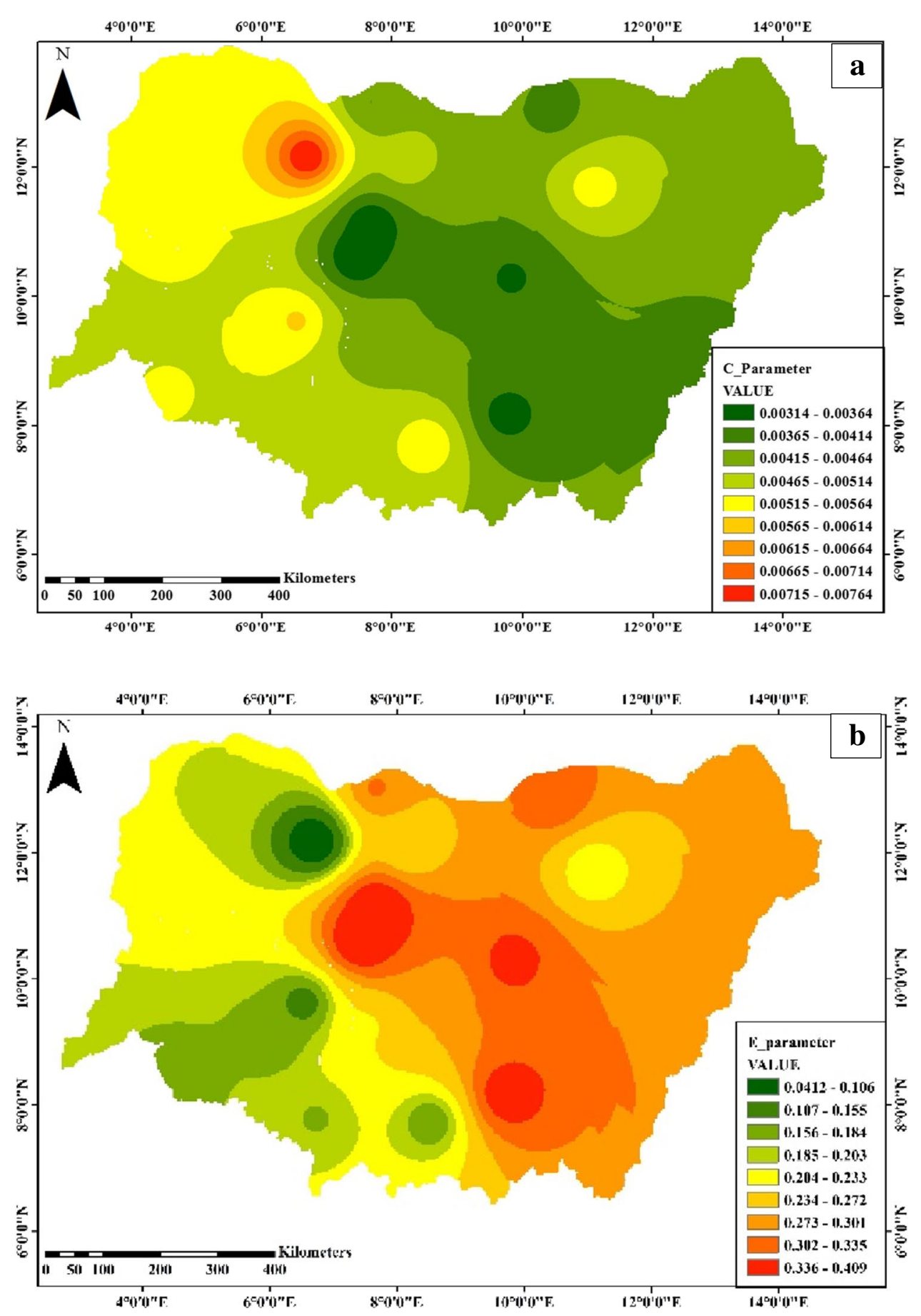

\subsection{Performance of original and calibrated HS in different climatic regions}

For a comprehensive evaluation of the study area along climatic regions, 19 local meteorological stations were selected. The annual averages of the meteorological parameters of the stations are highlighted in Table 1. Figures 6 and 7 show the efficiency of the original and calibrated HS ET equations as identified by RMSE, MAE, and $R$. After the calibration has been effected, the values of RMSE and MAE reduced significantly for all the climatic regions considered. The RMSE and MAE values obtained under the original HS model in the tropical (humid and sub-humid) climatic regions were lower than the ones in the arid and semi-arid regions. Although the RMSE and MAE values of the humid and sub-humid regions are smaller when compared to their arid and semi-arid counterparts, the $R$ values of the latter were higher than those of the earlier. This may be due to the 
Fig. 5 Maps showing variation in the statistical parameters calculated using the calibrated HS and FAO-56 PM models over the NRN: a MAE, b RMSE, and $\mathbf{c} R$
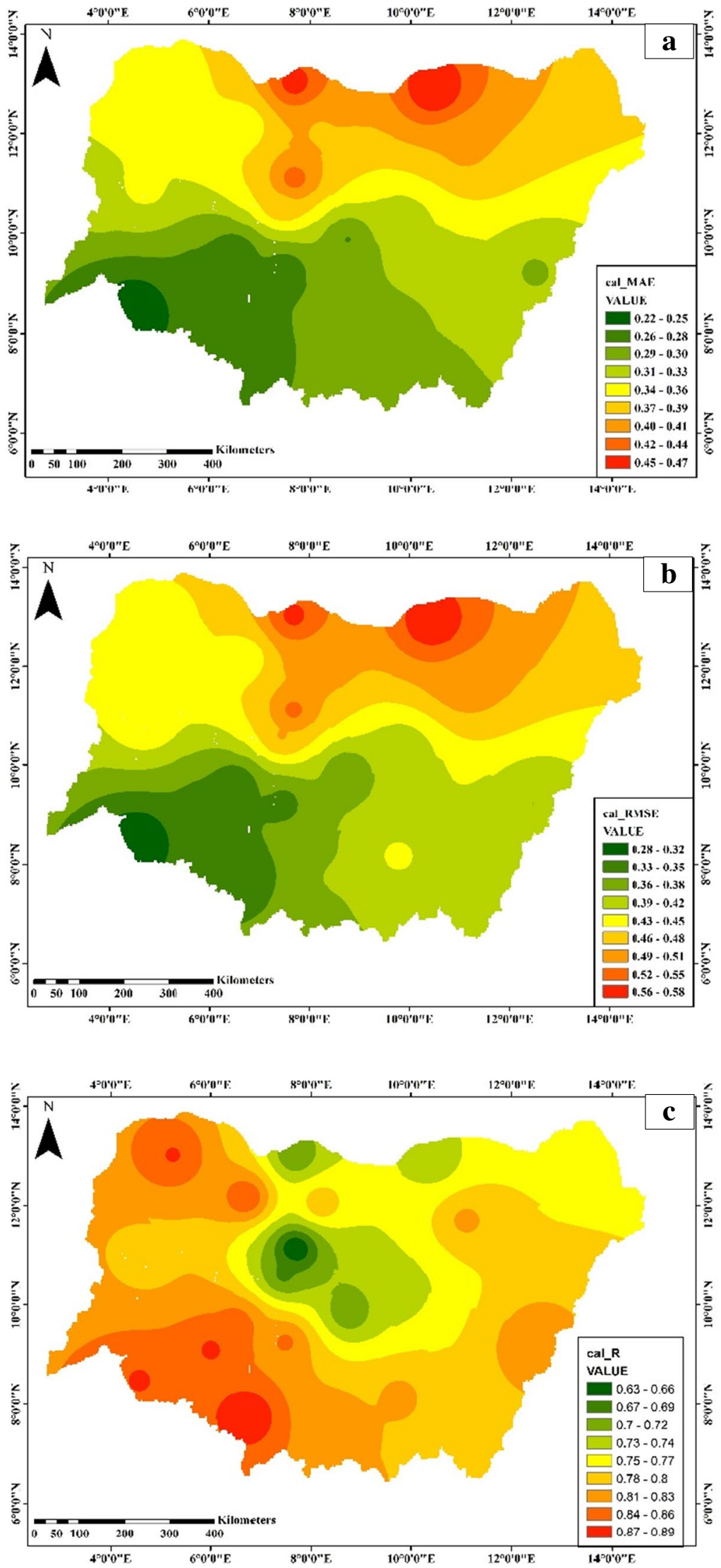
Table 3 Assessment of statistical parameters from the original and calibrated HS equations

\begin{tabular}{lllll}
\hline Statistics & HS & Min $\left(\mathrm{mm} \mathrm{day}^{-1}\right)$ & $\begin{array}{l}\text { Max }(\mathrm{mm} \\
\left.\text { day }^{-1}\right)\end{array}$ & $\begin{array}{l}\text { Aver- } \\
\text { age }(\mathrm{mm} \\
\left.\text { day }^{-1}\right)\end{array}$ \\
\hline RMSE & Original & 0.48 & 1.00 & 0.67 \\
& Calibrated & 0.28 & 0.58 & 0.42 \\
\multirow{2}{*}{ MAE } & Original & 0.41 & 0.87 & 0.58 \\
& Calibrated & 0.22 & 0.47 & 0.33 \\
& Original & 0.56 & 0.87 & 0.73 \\
& Calibrated & 0.63 & 0.89 & 0.79 \\
\hline
\end{tabular}

higher $\mathrm{ET}_{\mathrm{o}}$ values and fewer stations considered under the arid and semi-arid regions. It could also be due to the influence of the high variations in the relative humidity and wind speed during the Harmattan period that is more prevalent in the arid and semi-arid regions. Since these two important climate parameters (wind speed and relative humidity) are not considered in the development of HS equation, it is, however, necessary to recalibrate the HS equation using the prevalent climatic conditions of an area. The results illustrated in Fig. 7 show a better fit for all the climatic regions especially for the tropical regions. The observations from these results are similar to that of Zhu et al. (2019) which revealed that the calibrated $\mathrm{HS} \mathrm{ET}_{\mathrm{o}}$ equation for subtropical and tropical monsoon China performed well.

Figure 8 illustrates the $\mathrm{ET}_{\mathrm{o}}$ trends obtained from the $\mathrm{HS}$ and PM equations during the study period for four stations representing all the climatic regions in the NRN. The variation in the trend patterns of $\mathrm{ET}_{\mathrm{o}}$ values was moderately coherent during the calibration and validation phases. Due to the strong winds from the Sahara Desert that is more prominent during the dry season (i.e., usually between the months of November and February), the calibrated HS equation underestimated the $\mathrm{ET}_{\mathrm{o}}$ values during this season compared with the wet season. The disparity between the $\mathrm{ET}_{\mathrm{o}}$ values obtained from the calibrated HS and FAO-56 PM models was higher in the tropical regions than the arid and semi-arid climate regions. Relatively, Fig. 9a-d indicates a better performance for the calibrated HS than the original HS, although it was more obvious at Makurdi and Lokoja stations (i.e., sub-humid and humid regions). Figure 9a-d shows the $\mathrm{ET}_{\mathrm{o}}$ comparison obtained from the FAO-56 PM, original, and calibrated HS models for four representative stations during the study period. The coefficient of determination $\left(R^{2}\right)$ for the calibration and validation periods of the calibrated HS equation ranged from 0.48 to 0.78 and $0.52-0.83$, respectively, while that of the original HS model ranged from 0.31 to 0.58 . For all the four stations representing the climatic regions of the study area, the values of the statistical parameters for both calibration and validation phases are higher than those recorded for the original HS

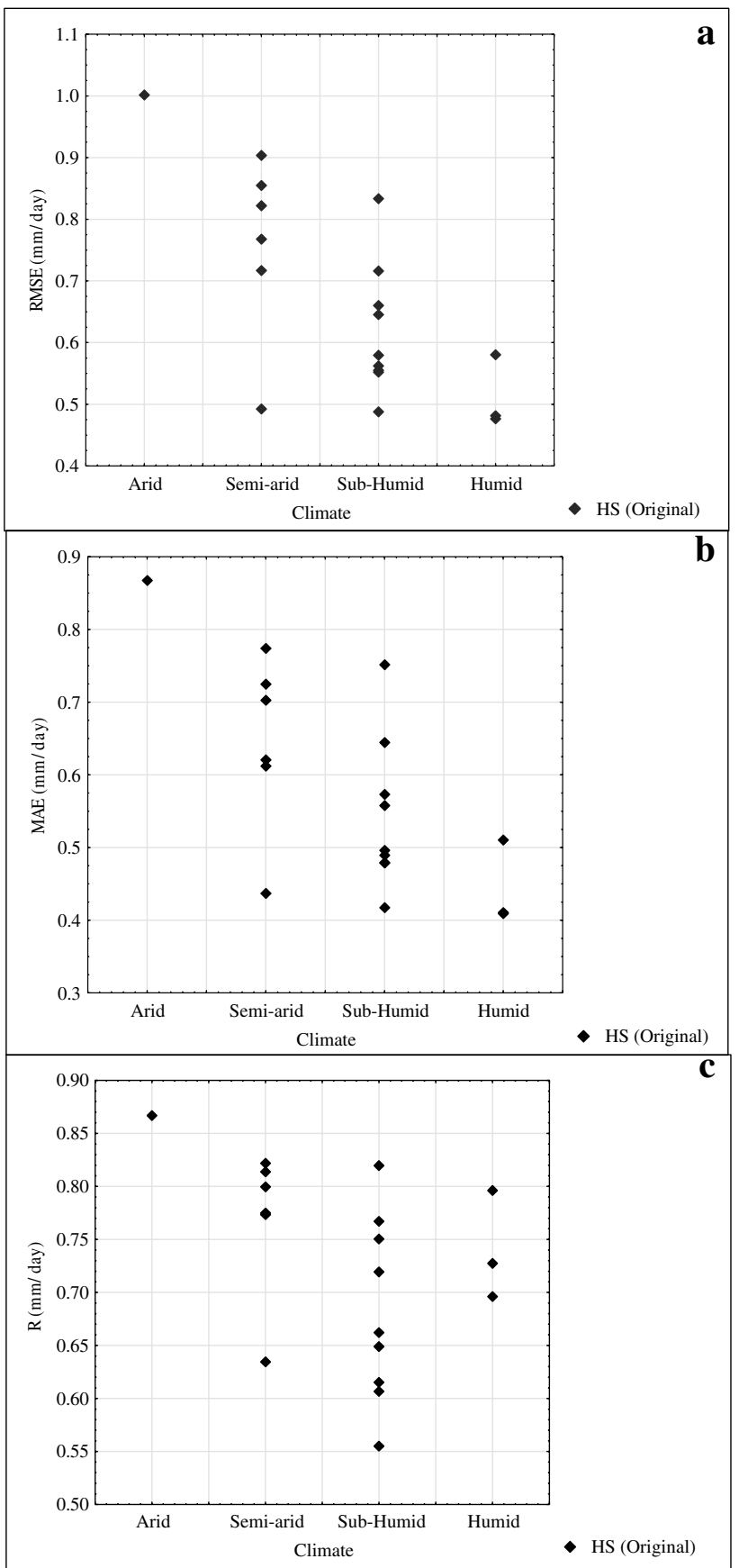

Fig. 6 Efficiency of the HS (original) $\mathrm{ET}_{\mathrm{o}}$ model for four climate classifications of the study area, as indicated by a RMSE, b MAE, and $\mathbf{c} R$

model. Also, the $R^{2}$ values decreased for the original HS model from the arid to the humid region, while the calibrated HS model got improved in the same pattern. Apart from the intense wind speed and low humidity that usually characterize arid and semi-arid regions, other factors that may be liable for the changes in the values recorded in various climate regions include location, altitude, terrain, extreme events, 


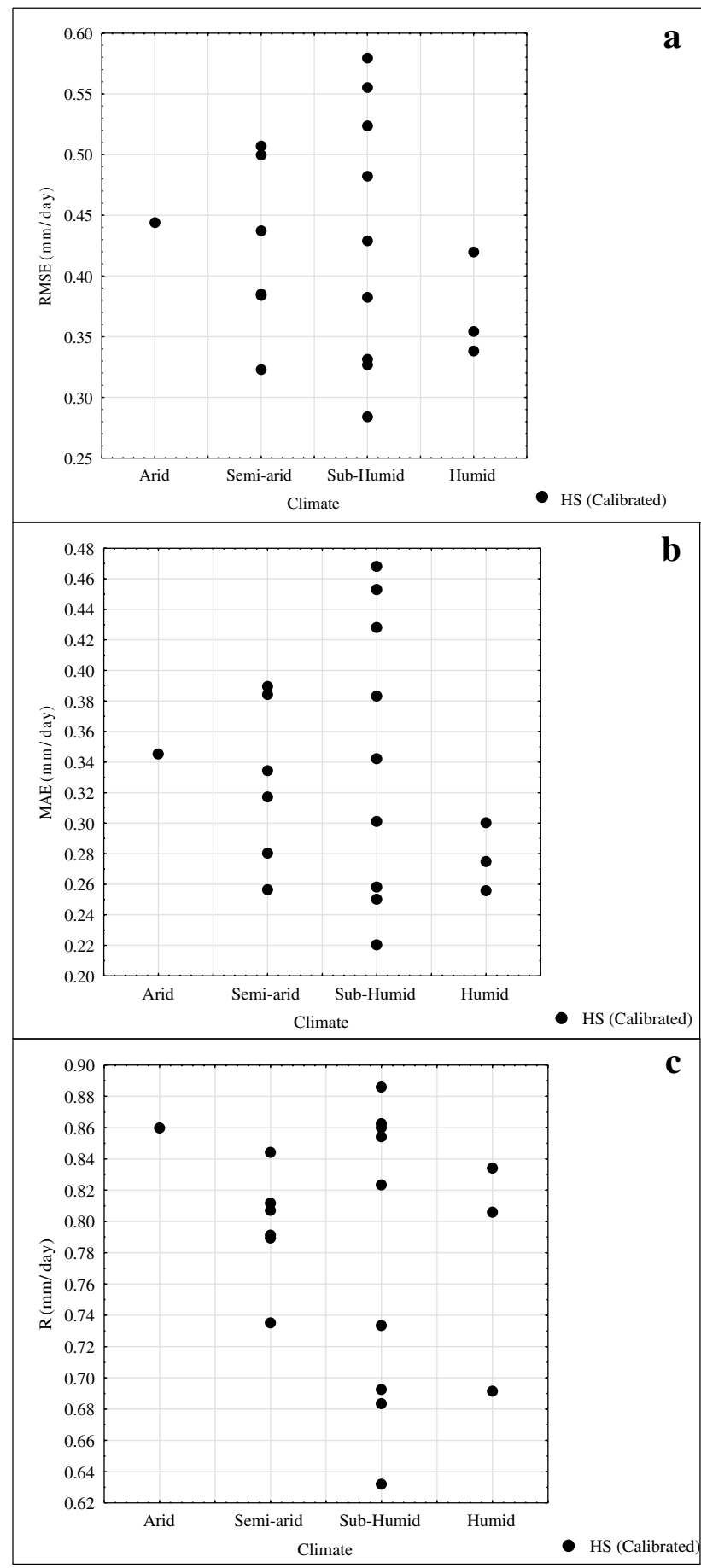

Fig. 7 Efficiency of the HS (calibrated) $\mathrm{ET}_{\mathrm{o}}$ model for four climate classifications of the study area, as indicated by a RMSE, b MAE, and $\mathbf{c} R$

and closeness to large river and ocean (Zhu et al. 2019). For instance, at lower latitudes, the range between daytime temperatures can become insignificant, thereby making HS model underestimate $\mathrm{ET}_{\mathrm{o}}$ (Almorox and Grieser 2016).
Some similarities could be noted between the four climate classes and the efficiency of the HS equations (original and calibrated) considering Figs. 8 and 9. Figure 9 shows that in the arid and semi-arid climatic regions, the regression lines drawn for calibrated HS model during the calibration and validation phases are closer to the line of best fit than that of the original HS model. Higher intercepts were noted for both original and calibrated HS under tropical climatic regions than for arid and semi-arid regions. This could have been responsible for more scattering of the observation points, thereby leading to a farther move away from the line of best fit unlike in the arid and semi-arid regions. Temesgen et al. (2005) suggested that the $\mathrm{ET}_{\mathrm{o}}$ values computed from the original HS equation would be lesser under a relative high wind speed and low relative humidity climate and greater under low/moderate wind speed and high humidity conditions. Also, just like Zhu et al. (2019) and Xu et al. (2012) observed over humid regions in China, the original HS model overestimated monthly $\mathrm{ET}_{\mathrm{o}}$ than the calibrated HS model.

Taking a critical look at the statistical analysis carried out, the calibrated HS equation can be advised more for the sub-humid and humid regions than at arid and semi-arid regions, while the original HS equation can be retained for some stations such as Sokoto, Bauchi, Kano, and Potiskum. At the abovementioned stations, the calibrated HS equation did not outperform the original HS equation. Moreover, even though the efficiency of HS model increased in most of the stations in sub-humid and humid regions, some stations such as Jos, Katsina, Kaduna, and Zaria still need to be improved on. Drawing from the results of the MAE, RMSE, and $R$ for some of the highlighted stations in the humid and sub-humid climates, it will be more efficient to use other methods to estimate $\mathrm{ET}_{\mathrm{o}}$ values for these stations. The observations noted among some stations that led to lack of improvement in the $\mathrm{ET}_{\mathrm{o}}$ values could be the prevailing role of the local climate.

\section{Conclusions}

This study used the FAO-56 PM ET $_{\mathrm{o}}$ equation to modify the $\mathrm{C}$ and $\mathrm{E}$ parameters in the original HS equation and assessed the efficiency of the calibrated HS equation based on climatic data from 19 stations across four climatic zones in the NRN. The summary of the key findings are as follows:

1. There was a general improvement the HS model after the calibration for all the four climatic regions; however, results under sub-humid and humid regions were significantly improved when compared with arid and semi-arid regions; 
Fig. 8 Monthly comparison of $\mathrm{ET}_{\mathrm{o}}$ by the original HS, modified HS (calibration and validation phases), and FAO-56 PM equations: a Nguru, b Katsina, c Makurdi, and d Lokoja
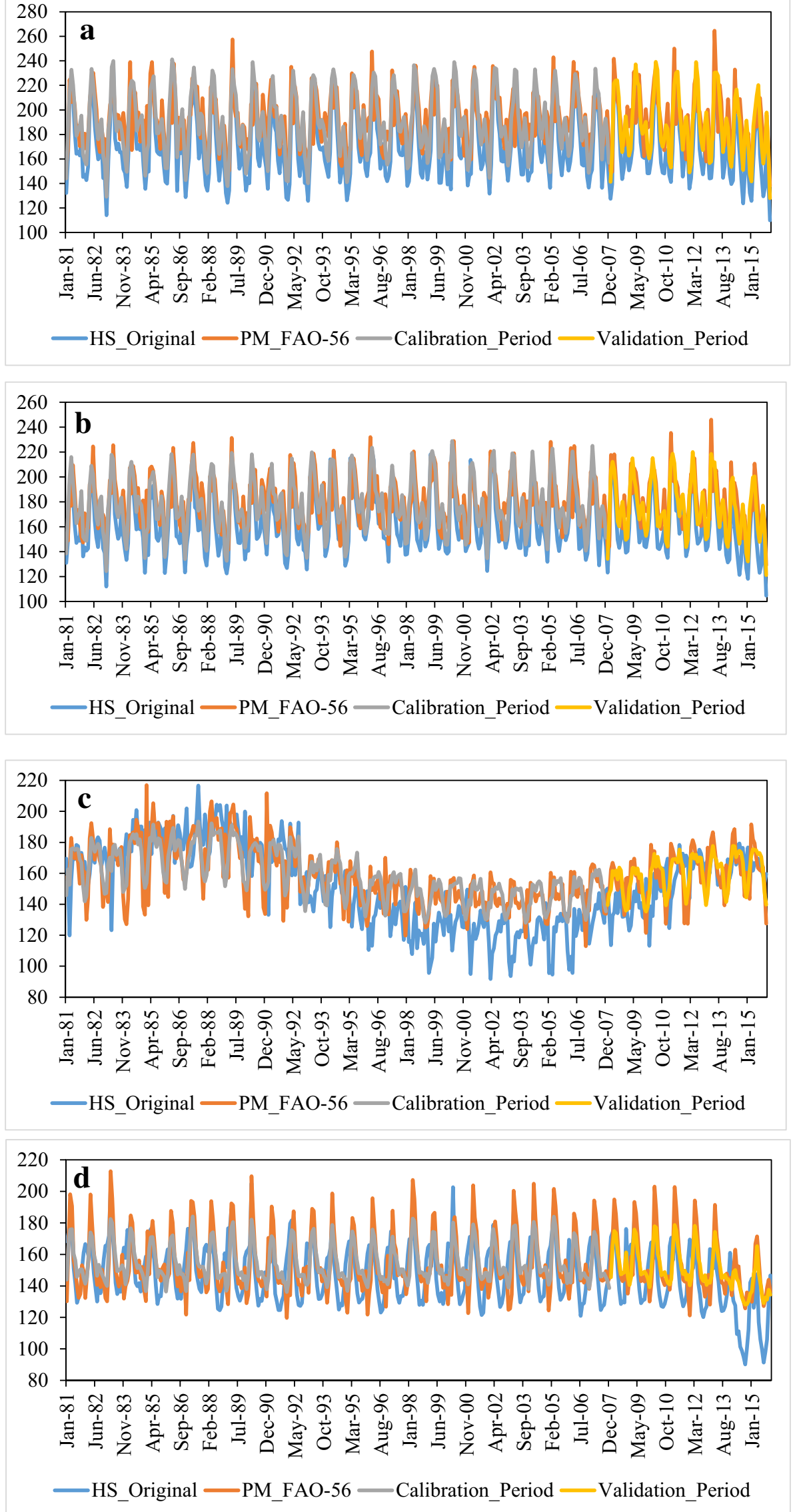
Fig. 9 Scatterplots of ETo calculated from the original HS, modified HS (calibration and validation phases), and FAO-56 PM equations: a Nguru, b Katsina, c Makurdi, and d Lokoja
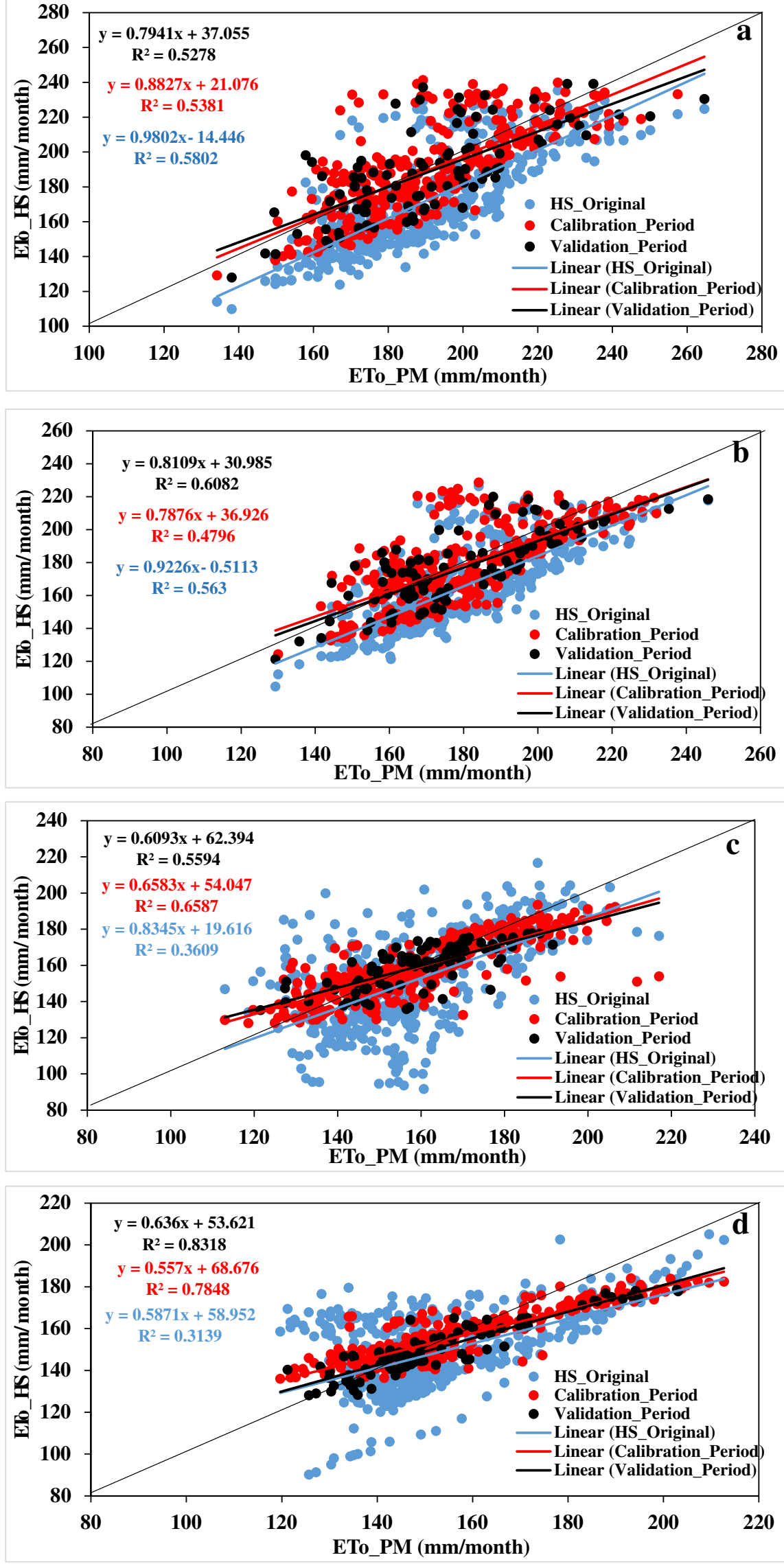
2. Based on the statistical analysis performed, the mean values of RMSE and MAE reduced from 0.67 to 0.42 and 0.58 to $0.33 \mathrm{~mm} \mathrm{day}^{-1}$, respectively. Likewise, the number of meteorological stations where $R$ value is greater than 0.8 increased from 6 to 11 . The coefficient of determination $\left(R^{2}\right)$ for the calibration and validation phases of the calibrated HS model for all the four climatic regions ranged from 0.48 to 0.78 and $0.52-0.83$, respectively, while that of the original HS model ranged from 0.31 to 0.58 . The $R^{2}$ values decreased from arid to humid region for the original HS model, while the calibrated HS equation increased in the same pattern. The precision of the HS equation increased significantly after calibration, especially for the humid and sub-humid regions. However, few stations in the humid and subhumid regions did not show significant improvement after calibration due to the peculiarity of the stations.

3. The calibrated HS equation indicates immense usefulness under local climate conditions. The results from the study also revealed that the calibrated HS equation is applicable for estimating $\mathrm{ET}_{\mathrm{o}}$ in all climatic regions. However, the performance can depend also on the temporal resolution of the data considered and some other geographical and climatological features of the area.

This study concentrated on the investigation of local distribution symmetries on a big spatial scale and elucidates the suitability of the HS equation in many climatic regions. The outcomes also make available a vital foundation for the estimation of $\mathrm{ET}_{\mathrm{o}}$ when there is paucity of data and provide more information for irrigation management. It is, however, recommended that other calibration procedures should be investigated for this study area using daily meteorological station data instead of monthly and a combination of satellite and observational data as used in this study.

Author contribution ATO: conceptualization, writing-original draft, software, formal analysis, visualization. IE, MAE: formal analysis, writing - original draft, visualization. TAA: data curation, writing, review and editing. QBP: supervision, writing, review, editing.

Availability of data and materials The data that support the findings of this study are available from the corresponding author (quoc_bao. pham@us.edu.pl) upon reasonable request.

Code availability The codes that support the findings of this study are available from the corresponding author (quoc_bao.pham@us.edu.pl).

\section{Declarations}

Conflict of interest The authors declare no competing interests.
Open Access This article is licensed under a Creative Commons Attribution 4.0 International License, which permits use, sharing, adaptation, distribution and reproduction in any medium or format, as long as you give appropriate credit to the original author(s) and the source, provide a link to the Creative Commons licence, and indicate if changes were made. The images or other third party material in this article are included in the article's Creative Commons licence, unless indicated otherwise in a credit line to the material. If material is not included in the article's Creative Commons licence and your intended use is not permitted by statutory regulation or exceeds the permitted use, you will need to obtain permission directly from the copyright holder. To view a copy of this licence, visit http://creativecommons.org/licenses/by/4.0/.

\section{References}

Adeboye OB, Osunbitan JA, Adekalu KO, Okunade DA (2009) Evaluation of FAO-56 Penman-Monteith and temperature based models in estimating reference evapotranspiration using complete and limited data, application to Nigeria. Agricultural Engineering International: the CIGR Ejournal. Manuscript number 1291. Volume XI.

Akpootu DO, Iliyasu MI (2017) A comparison of various evapotranspiration models for estimating reference evapotranspiration in Sokoto, North Western. Nigeria Physical Science International Journal 14(2):1-14. https://doi.org/10.9734/PSIJ/2017/32720

Allen RG, Pereira LS, Raes D, Smith M (1998) Crop evapotranspiration: guidelines for computing crop water requirements. FAO Irrigation and Drainage Paper No. 56. FAO: Rome, Italy.

Almorox J, Grieser J (2016) Calibration of the Hargreaves-Samani method for the calculation of reference evapotranspiration in different Köppen climate classes. Hydrol Res. https://doi.org/ 10.2166/nh.2015.091

Animashaun IM, Oguntunde PG, Akinwumiju AS, Olubanjo OO (2020) Rainfall analysis over the Niger Central Hydrological Area, Nigeria: variability, trend, and change point detection. Scientific African. https://doi.org/10.1016/j.sciaf.2020.e00419

Azhar AH, Perera BJC (2011) Evaluation of reference evapotranspiration estimation methods under south east Australian conditions. J Irrig Drain Eng 137:268-279

Barati R (2013) Application of Excel Solver for parameter estimation of the nonlinear Muskingum models. KSCE J Civ Eng 17(5):1139-1148. https://doi.org/10.1007/s12205-013-0037-2

Berrisford P, Kallberg P, Kobayashi S, Dee D, Uppala S, Simmons AJ, Poli P, Sato H (2011) Atmospheric conservation properties in ERA-Interim. J R Meteorol Soc 137:659. https://doi.org/10. 1002/qj.864

Bogawski P, Bednorz E (2014) Comparison and validation of selected evapotranspiration models for conditions in Poland (Central Europe). Water Resour Manage 28:5021-5038

Comas J, Connor D, Isselmou EM, Mateos ML, Gómez-Macpherson $H$ (2012) Why has small-scale irrigation not responded to expectations with traditional subsistence farmers along the Senegal River in Mauritania? Agric Syst 110:152-161

Dai A, Lamb PJ, Trenberth KE, Hulme M, Jones PD, Xie P (2004) Comment: The recent Sahel drought is real. Int J Climatol 24:1323-1331. https://doi.org/10.1002/joc.1083

Djaman K, Balde AB, Sow A, Muller B, Irmak S, Ndiaye MK, Manneh B, Moukoumbi YD, Futakuchi K, Saito K (2015) Evaluation of sixteen reference evapotranspiration methods under sahelian conditions in the Senegal River Valley. J. Hydrol.: Reg. Stud 3:139-159

Dong B, Sutton R (2015) Dominant role of greenhouse-gas forcing in the recovery of Sahel rainfall. Nature Climate Change Letters. https://doi.org/10.1038/NCLIMATE2664 
Ejieji CJ (2011) Performance of three empirical reference evapotranspiration models under three sky conditions using two solar radiation estimation methods at Ilorin, Nigeria. Agricultural Engineering International: CIGR J. Manuscript No.1673. Vol. 13 , No.3

Fooladmand HR, Sepaskhah AR (2005) Regional calibration of Hargreaves equation in a semi-arid region. Water Resour Res 1:1-6

Gao X, Peng S, Xu J, Yang S, Wang W (2015) Proper methods and its calibration for estimating reference evapotranspiration using limited climatic data in Southwestern China. Arch Agron Soil Sci 61(3):415-426

Gavilan P, Lorite IJ, Tornero S, Berengena J (2006) Regional calibration of Hargreaves equation for estimating reference ET in a semiarid environment. Agric Water Manag 81(3):257-281

Ghamarnia H, Rezvani V, Khodaei E, Mirzaei H (2012) Time and place calibration of the Hargreaves equation for estimating monthly reference evapotranspiration under different climatic conditions. J Agric Sci 4:111-122

Gocic M, Trajkovic S (2013) Analysis of changes in meteorological variables using Mann-Kendall and Sen's slope estimator statistical tests in Serbia. Global Planetary Change 100(100):172-182. https://doi.org/10.1016/j.gloplacha.2012.10.014

Hargreaves GH (1994) Defining and using reference evapotranspiration. J Irrig Drain Eng 120(6):1132-1139

Hargreaves GH, Samani ZA (1985) Reference crop evapotranspiration from temperature. Appl Eng Agric 1(2):96-99

Heydari MM, Heydari M (2014) Calibration of Hargreaves-Samani equation for estimating reference evapotranspiration in semiarid and arid regions. Archives of Agronomy and Soil Science 60(5):695-713. https://doi.org/10.1080/03650340.2013.808740

Ibebuchi CC (2021) On the relationship between circulation patterns, the Southern Annular Mode, and rainfall variability in Western Cape. Atmosphere 12(6):753. https://doi.org/10.3390/atmos12060 753

Jerin JN, Islam HMT, Islam ARMT, Shahid S, Hu Z, Badhan MA, Chu R, Elbeltagi A (2021) Spatiotemporal trends in reference evapotranspiration and its driving factors in Bangladesh. Theoret Appl Climatol 144:793-808. https://doi.org/10.1007/ s00704-021-03566-4

Lasdon LS, Smith S (1992) Solving sparse nonlinear programs using GRG. ORSA J Comput 4(1):2-15

Lele MI, Lamb PJ (2010) Variability of the Intertropical Front (ITF) and rainfall over the West African Sudan-Sahel Zone. J Clim 23:3984-4004. https://doi.org/10.1175/2010JCLI3277.1

Li M, Chu R, Islam ARMT, Shen S (2018) Reference evapotranspiration variation analysis and its approaches. Evaluation of 13 empirical models in sub-humid and humid regions: a case study of the Huai River Basin. Eastern China. Water 10(493):1-22. https://doi. org/10.3390/w10040493

Mohammadi B, Mehdizadeh S (2020). Modeling Daily Reference Evapotranspiration via a Novel Approach Based on Support Vector Regression Coupled with Whale Optimization Algorithm. https://doi.org/10.1016/j.agwat.2020.106145

Ogunrinde AT, Oguntunde PG, Fasinmirin JT, Akinwumiju AS (2020a) Application of artificial neural network for forecasting standardized precipitation and evapotranspiration index: a case study of Nigeria. Engineering Reports 2(7):1-18. https://doi.org/10.1002/ eng2.12194

Ogunrinde AT, Olasehinde DA, Olotu Y (2020b) Assessing the sensitivity of standardized precipitation evapotranspiration index to three potential evapotranspiration models in Nigeria. Scientific African. https://doi.org/10.1016/j.sciaf.2020.e00431

Oguntunde PG, Abiodun BJ, Lischeid G (2011) Rainfall trends in Nigeria, 1901-2000. J Hydrol 411(3-4):207-218
Oluleye A, Adeyewa D (2016) Wind energy density in Nigeria as estimated from the ERA interim reanalysed data set. Br J Appl Sci Technol 17(1):1-17

Pandey V, Pandey PK, Mahanta AP (2014) Calibration and performance verification of Hargreaves Samani equation in a humid region. Irrig and Drain. https://doi.org/10.1002/ird.1874

Pereira AR, Pruitt WO (2004) Adaptation of the Thornthwaite scheme for estimating daily reference evapotranspiration. Agric Water Manag 66:251-257

Premium Solver Platform, User Guide (2010). Frontline Systems, Inc., Notes downloaded from the site http://www.solver.com

Rivas R, Caselles VA (2004) Simplified equation to estimate spatial reference evaporation from remote sensing-based surface temperature and local meteorological data. Remote Sens Environ 93:68-76

Salam R, Islam ARMT (2020) Potential of RT, Bagging and RS ensemble learning algorithms for reference evapotranspiration prediction using climatic data-limited humid region in Bangladesh. J Hydrol. https://doi.org/10.1016/j.jhydrol.2020.125241

Stockle CO, Kjelgaard J, Bellocchi G (2004) Evaluation of estimated weather data for calculating Penman-Monteith reference crop evapotranspiration. Irrig Sci 23:39-46

Sultan B, Janicot S (2000) Abrupt shift of the ITCZ over West Africa and intra-seasonal variability. Geophys Res Lett 27(20):3353-3356

Tellen VA (2007) A comparative analysis of reference evapotranspiration from the surface of rainfed grass in Yaounde, calculated by six empirical methods against the Penman Monteith formula. Earth Perspectives 4:4. https://doi.org/10.1186/s40322-017-0039-1

Temesgen B, Eching S, Davidoff B, Frame K (2005) Comparison of some reference evapotranspiration equations for California. J Irrig Drain Eng 131(1):73-84

Thepadia M, Martinez CJ (2012) Regional calibration of solar radiation and reference evapotranspiration estimates with minimal data in Florida. J Irrig Drain Eng 138:111-119

Trajkovic S (2005) Temperature-based approaches for estimating reference evapotranspiration. J Irrig Drain Eng 131(4):316-323

UNEP (United Nations Environmental Programme) (1992) World atlas of desertification. New York, NY: United Nations

Valipour M (2015) Investigation of Valiantzas' evapotranspiration equation in Iran. Theor Appl Climatol 121(1):267-278

Xu JZ, Peng SZ, Yang SH, Luo YF, Wang YJ (2012) Predicting daily reference evapotranspiration in a humid region of China by the locally calibrated Hargreaves-Samani equation using weather forecast data. J Agric Sci Technol 14(6):1331-1342

Xu J, Peng S, Ding J, Wei Q, Yu Y (2013) Evaluation and calibration of simple methods for daily reference evapotranspiration estimation in humid East China. Archives of Agronomy and Soil Science 59(6):845-858

Zhu X, Luo T, Luo Y, Ynag Y, Guo L, Luo H, Fang C, Cui Y (2019) Calibration and validation of the Hargreaves-Samani model for reference evapotranspiration estimation in China. Irrig and Drain. https://doi.org/10.1002/ird.2350

Zinat MRM, Salam R, Badhan MA, Islam ARMT (2020) Appraising drought hazard during Boro rice growing period in western Bangladesh. Int J Biometeorol. https://doi.org/10.1007/ s00484-020-01949-2

Publisher's Note Springer Nature remains neutral with regard to jurisdictional claims in published maps and institutional affiliations. 